\title{
Temporal expression and signalling of prostacyclin receptor in the human endometrium across the menstrual cycle
}

\author{
S Battersby, H O D Critchley ${ }^{1}$, A J de Brum-Fernandes ${ }^{2}$ and $\mathrm{H}$ N Jabbour \\ MRC Human Reproductive Sciences Unit and ${ }^{1}$ Department of Reproductive and Developmental Sciences, \\ Centre for Reproductive Biology, University of Edinburgh Chancellor's Building, 49 Little France Crescent, \\ Old Dalkeith Road, Edinburgh EH16 4SB, UK and ${ }^{2}$ Rheumatic Diseases Unit, Centre Universitaire de Santé de \\ I'Estrie, 3001-12 Avenue Nord, Fleurimont, PQ, Canada J1H 5N4
}

Correspondence should be addressed to H N Jabbour; Email: h.jabbour@hrsu.mrc.ac.uk

\begin{abstract}
Prostacyclin $\left(\mathrm{PGI}_{2}\right)$ synthesis and function in the human uterus has been implicated in the regulation of the process of normal and dysfunctional menstruation. $\mathbf{P G I}_{2}$ synthesis is elevated during normal menstruation and is also associated with blood loss in women who suffer from heavy menses. This study was designed to outline further the role of $\mathrm{PGl}_{2}$ in menstruation by investigating the temporal pattern and site of expression of prostaglandin I synthase (PGIS) and the prostacyclin receptor (IP receptor) in the non-pregnant human endometrium across the menstrual cycle. Quantitative RT-PCR demonstrated increased expression of PGIS and IP receptor during the menstrual phase of the cycle compared with all other phases $(P<0.05)$. Furthermore, PGIS and IP receptor were localised to the glandular epithelium, stromal and endothelial cells in the basal and functional layers of the endometrium. Functionality of the IP receptor in the human endometrium was assessed by measuring cAMP generation following treatment with $100 \mathrm{nmolI}^{-1}$ of the $\mathrm{PGI}_{2}$ analogue, iloprost. cAMP generation was significantly higher in endometrial tissue collected during the proliferative compared with the secretory phase of the menstrual cycle $(P<0.05)$.
\end{abstract}

In conclusion, this study has confirmed increased expression and signalling of PGIS and IP receptor during the menstrual phase and outlines a potential autocrine/paracrine role for $\mathbf{P G I}_{2}$ on several cellular compartments in the endometrium including the endothelium. This may underscore a pivotal role for $\mathrm{PGI}_{2}$ receptor signalling in normal and dysfunctional menstruation.

Reproduction (2004) 127 79-86

\section{Introduction}

Prostacyclin $\left(\mathrm{PGI}_{2}\right)$ is a member of the prostanoid family of lipid mediators and is the main prostanoid synthesised by vascular endothelium (Smyth \& FitzGerald 2002). Cyclooxygenase (COX) enzyme is the key enzyme in the synthesis of $\mathrm{PGI}_{2}$ from arachidonic acid via the common intermediate in prostaglandin (PG) synthesis, $\mathrm{PGH}_{2}$. In turn, $\mathrm{PGH}_{2}$ is rapidly converted to $\mathrm{PGI}_{2}$ by the action of prostaglandin I synthase (PGIS) (Kniss 1999). There are two predominant isoforms of COX enzymes, COX-1, which is constitutively expressed in many cell types and COX-2, which is induced by factors including cytokines and tumour promoters (Kniss 1999). $\mathrm{PGI}_{2}$ elicits its effects on target cells by interaction with its $G$ protein-coupled receptor (IP receptor), which has a typical seven-transmembrane structure (Narumiya et al. 1999). The IP receptor can stimulate both $\mathrm{G}_{\mathrm{s}}$ and $\mathrm{G}_{\mathrm{q}}$ species of $\mathrm{G}$ proteins causing an increase in CAMP generation and in phosphatidylinositol response (Narumiya et al. 1999).

Temporal expression of other prostaglandins such as $\mathrm{PGE}_{2}$ and $\mathrm{PGF}_{2 \alpha}$ and their receptors (EP2/EP4 and FP receptors) has been demonstrated in the human endometrium and has been shown to vary with the phase of the menstrual cycle (Lumsden et al. 1986, Smith \& Kelly 1988, Milne et al. 2001, Milne \& Jabbour 2003). Maximal expression and signalling of these receptors are detected during the mid-late proliferative phase of the menstrual cycle. Recent data implicate a role for $\mathrm{PGE}_{2}$ and $\mathrm{PGF}_{2 \alpha}$ in the proliferation of glandular epithelial cells via diverse signalling pathways (Jabbour \& Boddy 2003, Milne \& Jabbour 2003). In contrast, little is known of the expression pattern and function of the IP receptor in human endometrium, although PGIS and IP receptor expression have been demonstrated in pregnant and non-pregnant myometrium (Moonen et al. 1986, Chegini \& Rao 1988, Giannoulias et al. 2002). 
$\mathrm{PGI}_{2}$ is the main prostanoid synthesised by the vascular endothelium and it causes blood vessel dilatation and inhibition of platelet aggregation (Smyth \& FitzGerald 2002). Moreover, $\mathrm{PGI}_{2}$ is known to act as a smooth muscle relaxant (Wilhelmsson et al. 1981, Lumsden \& Baird 1986, Dyal \& Crankshaw 1988). The effects of $\mathrm{PGI}_{2}$ on platelet aggregation and vascular tone have outlined its potential role in menstruation (Baird et al. 1996). This is supported by observations of elevated $\mathrm{PGI}_{2}$ levels in uterine venous blood during menstruation as compared with other phases of the menstrual cycle (Goodfellow et al. 1982). Moreover, $\mathrm{PGI}_{2}$ synthesis is increased in women suffering from heavy menses compared with those who show normal blood loss (Smith et al. 1981b, Makarainen \& Ylikorkala 1986, Cameron et al. 1987). It has also been suggested that menstrual disorders can be the result of a shift in the ratio of different prostaglandins. Heavy menses has been associated with increased synthesis of $\mathrm{PGI}_{2}$ relative to thromboxane $\mathrm{A}_{2}$ and $\mathrm{PGE}_{2}$ relative to $\mathrm{PGF}_{2 \alpha}$ (Smith et al. 1981a, Makarainen \& Ylikorkala 1986). Heavy menses with no known uterine pathology affects $10 \%$ of women of child bearing age and is defined as blood loss in excess of $80 \mathrm{ml}$ per menstrual cycle (Prentice 2000).

The objectives of the present study were to investigate the expression of PGIS (the terminal enzyme responsible for the generation of $\mathrm{PGI}_{2}$ ) and IP receptor in nonpregnant human endometrium and myometrium across the menstrual cycle. Furthermore, the role of $\mathrm{PGI}_{2}$ in endometrial cell signalling has been assessed by investigating the effect of the $\mathrm{PGI}_{2}$ analogue, iloprost, on cAMP generation. A better understanding of IP receptor signalling and function in the human endometrium may ultimately lead to the development of novel therapies in the treatment of menstrual disorders that may be associated with elevated $\mathrm{PGI}_{2}$ synthesis.

\section{Materials and Methods}

\section{Patients and tissue collection}

Endometrial biopsies at different stages of the menstrual cycle were obtained from women with regular menstrual cycles (25-35 days), who had not received a hormonal preparation in the 3 months preceding biopsy collection. Samples were collected either with an endometrial suction curette (Pipelle, Laboratoire CCD, Paris, France) or as full thickness endometrial biopsies (including the functional layer and basal-myometrial junction) from women undergoing hysterectomy for benign gynaecological indications. Shortly after collection, tissue was either snap frozen in dry ice and stored at $-70^{\circ} \mathrm{C}$ (for RNA extraction), fixed in neutral buffered formalin (NBF) and wax embedded (for immunohistochemical analyses), or placed in RPMI 1640 (containing $2 \mathrm{mmol} \mathrm{I}^{-1}$ L-glutamine, $100 \mathrm{U}$ penicillin and $100 \mu \mathrm{g} \mathrm{ml}^{-1}$ streptomycin) and transported to the laboratory for in vitro culture.
Biopsies were classified within a 28-day cycle range using stated last menstrual period (LMP) and histological assessment according to the criteria of Noyes and co-workers (1975). Furthermore, circulating oestradiol and progesterone concentrations at the time of biopsy were consistent for both stated LMP and histological assignment of menstrual cycle stage. Samples were divided according to the phase of the menstrual cycle as: menstrual (days 1-4), early to mid proliferative (EP-MP; days 5-10), late proliferative to ovulatory (LP-Ov; days 11-14), early secretory (ES; days 15-18) and mid to late secretory (MSLS; days 19-28). Ethical approval was obtained from the Lothian Research Ethics Committee and written informed consent was obtained from all subjects before tissue collection.

\section{Taqman quantitative RT-PCR}

RNA was extracted from endometrial biopsies obtained from across the menstrual cycle $(n=35)$ using Tri Reagent (Sigma, Poole, Dorset, UK) following the manufacturer's instructions. RNA samples were quantified and were reverse transcribed using $5.5 \mathrm{mmoll}^{-1} \mathrm{MgCl}_{2}, 0.5 \mathrm{mmol} \mathrm{I}^{-1}$ of each deoxynucleotide triphosphate (dNTP), $2.5 \mu \mathrm{mol} \mathrm{I}^{-1}$ random hexamers, ribonuclease inhibitor $\left(0.4 \cup \mu l^{-1}\right)$ and $1.25 \mathrm{U} \mathrm{ul}^{-1}$ Multiscribe reverse transcriptase (all from Applied Biosystems, Warrington, Cheshire, UK). RNA (400 ng) was added to each reverse transcription reaction and samples were incubated for $90 \mathrm{~min}$ at $25^{\circ} \mathrm{C}, 45 \mathrm{~min}$ at $48^{\circ} \mathrm{C}$ and $5 \mathrm{~min}$ at $95^{\circ} \mathrm{C}$. The reaction mix for the PCR consisted of $1 \times$ mastermix, ribosomal $18 \mathrm{~S}$ forward and reverse primers, ribosomal $18 \mathrm{~S}$ probe $\left(50 \mathrm{nmoll}^{-1}\right.$; all from Applied Biosystems), forward and reverse primers for PGIS or IP receptor $\left(300 \mathrm{nmol} \mathrm{I}^{-1}\right)$ and PGIS or IP receptor probe $\left(200 \mathrm{nmolI}^{-1}\right.$ ) (all from Biosource UK, Nivelles, Belgium). The reaction mix $(48 \mu \mathrm{l})$ was aliquoted into tubes and $2 \mu \mathrm{l}$ cDNA were added. Duplicate $24 \mu \mathrm{l}$ samples plus positive and negative controls were placed in a PCR plate and wells were sealed with optical caps. The PCR reactions were carried out using an $\mathrm{ABI}$ Prism 7700 (Applied Biosystems). All primers and probes were designed using the PRIMER express program (Applied Biosystems). The sequences of PGIS primers and probe were: PGIS forward primer, 5' ${ }^{\prime}$-ACGCAGATGTGGAGATCCCT-3'; reverse, 5'-GTCGTGTTCCGGCTGCA-3'; and probe (6-carboxy fluoroscein labelled) $5^{\prime}$-CCTCAGCAGGTACGGCTTCGGTCTG-3 ${ }^{\prime}$. The sequences of the IP receptor primers and probe were: IP receptor forward primer, 5'-GCCCTCCCССТСТАСCAA-3'; reverse, 5'-TTTTCCAATAACTGTGGTTTTTGTG-3'; and probe (6-carboxy fluoroscein labelled) 5'-CCAAGAGCCAGCCCCCTTTCTGC-3'. The sequences of $18 \mathrm{~S}$ primers and probe have been described previously (Milne et al. 2001). Data were analysed and processed using Sequence Detector version 1.6.3 (Applied Biosystems) according to the manufacturer's instructions. Results were expressed relative to an internal positive standard 
(cDNA obtained from a single sample of endometrial tissue) included in all reactions.

\section{In situ hybridisation}

A custom synthesised oligonucleotide double fluoroscein isothiocyanate (FITC)-labelled cDNA probe for IP receptor was obtained from Biognostik (Göttingen, Germany). Sections $(5 \mu \mathrm{m})$ from full thickness human endometrial biopsies collected across the menstrual cycle $(n=12)$ were cut onto gelatin-coated slides. Sections were dewaxed and rehydrated and then treated with proteinase $\mathrm{K}$ $\left(50 \mu \mathrm{gl}^{-1}\right.$ in $100 \mathrm{mmol} \mathrm{I}^{-1}$ Tris $-\mathrm{HCl} \mathrm{pH} \mathrm{7.6,} \mathrm{containing}$ $50 \mathrm{mmol} \mathrm{I}^{-1}$ EDTA) for $15 \mathrm{~min}$ at $37^{\circ} \mathrm{C}$ to enhance cDNA probe access. Sections were washed in diethylpyrocarbonate-treated water and prehybridised for $4 \mathrm{~h}$ at $30^{\circ} \mathrm{C}$ with $25 \mu \mathrm{l}$ of the hybridisation buffer supplied with the probe, which had previously been heated to $95^{\circ} \mathrm{C}$. The sections were then hybridised overnight at $30^{\circ} \mathrm{C}$ with the cDNA probe at $6 \cup \mu l^{-1}$ in hybridisation buffer. Following hybridisation, sections were washed for $2 \times 5 \mathrm{~min}$ in $1 \times$ SSC at room temperature and $2 \times 15 \mathrm{~min}$ in $0.1 \times$ SSC at $39^{\circ} \mathrm{C}$. After rinsing in tris buffered saline (TBS), endogenous peroxidase activity was quenched with $10 \%$ $(\mathrm{v} / \mathrm{v}) \mathrm{H}_{2} \mathrm{O}_{2}$ in methanol at room temperature. The FITClabelled probe was detected using standard immunohistochemical reagents with an additional amplification step (TSA Biotin System, NEN Life Science Products, Hounslow, Middlesex, UK). Sections were incubated with blocking buffer for $30 \mathrm{~min}$. Conjugated anti-FITC-horseradish peroxidase (Roche, Diagnostics Ltd, Lewes, E Sussex, UK) was added at a dilution of 1 in 200 in blocking buffer and the sections were incubated for $30 \mathrm{~min}$. After washing, biotinyl tyramide amplification reagent (1 in 50) was applied to each slide and incubated for $15 \mathrm{~min}$. Streptavidin-horseradish peroxidase (1 in 100) was applied after washing and incubated for $30 \mathrm{~min}$; probe localisation was visualised with 3,3'-diaminobenzidine (DAB) substrate. Control sections were treated with a double FITClabelled oligonucleotide probe containing the same proportion of cysteine $(\mathrm{C})$ and guanine $(\mathrm{G})$ bases as the IP receptor probe to assess background hybridisation. All treatments were carried out at room temperature unless otherwise specified.

\section{Immunohistochemistry}

Endometrial sections $(5 \mu \mathrm{m})$ from across the menstrual cycle $(n=12)$ were dewaxed in xylene and rehydrated using decreasing grades of ethanol. Antigen retrieval was performed by treating sections for $5 \mathrm{~min}$ in a pressure cooker in boiling $0.1 \%$ citrate buffer, $\mathrm{pH} 3.0$. Endogenous peroxidase activity was quenched with $10 \%(\mathrm{v} / \mathrm{v}) \mathrm{H}_{2} \mathrm{O}_{2}$ in methanol at room temperature. Non-immune swine serum (20\% serum in TBS) was applied for $1 \mathrm{~h}$ before overnight incubation at $4{ }^{\circ} \mathrm{C}$ with rabbit anti-human IP receptor at a dilution of 1 in 500 or rabbit anti-bovine PGIS (shown to cross-react with human PGIS) (Alexis Corporation, Nottingham, UK) at the same concentration. An avidinbiotin peroxidase detection system was then applied (DAKO Ltd, Cambridge, UK) with DAB as the chromagen. The antibody to IP receptor has been described previously (Fortier et al. 2001). Non-immune rabbit serum and antibody pre-absorbed with IP receptor peptide were used as controls for IP receptor, and non-immune rabbit serum was used as a control for PGIS. Immunoreactivity was negligible with pre-absorbed antibody, and with nonimmune rabbit serum there was occasional generalised pale brown cross reactivity over the epithelial glands and the endothelium.

\section{Cyclic AMP assay}

Endometrial biopsies from the proliferative and secretory phases of the menstrual cycle $(n=8)$ were minced finely with scissors and divided into three portions. The tissue was incubated overnight at $37^{\circ} \mathrm{C}$ in a humidified $5 \% \quad \mathrm{CO}_{2}$ incubator in $2 \mathrm{ml}$ RPMI medium (Sigma) containing $2 \mathrm{mmolI}^{-1}$ L-glutamine, $100 \mathrm{IU}$ penicillin and $100 \mu \mathrm{g}$ streptomycin, and $3 \mu \mathrm{g} \mathrm{ml}^{-1}$ indomethacin (Sigma). Following overnight treatment, the tissue was incubated in the same medium containing 1-methyl-3-isobutylxanthine (Sigma) at $37^{\circ} \mathrm{C}$ for $30 \mathrm{~min}$. It was then treated with control medium or $100 \mathrm{nmol} \mathrm{I}^{-1}$ iloprost (a gift from Schering Health Care, Burgess Hill, W Sussex, UK) for $10 \mathrm{~min}$ at $37^{\circ} \mathrm{C}$ and lysed in $0.1 \mathrm{moll}^{-1} \mathrm{HCl}$ and frozen until assayed. Cyclic AMP concentration was measured by ELISA (Biomol, Affiniti, Exeter, Devon, UK) according to the manufacturer's instructions and normalised to the protein concentration determined by a modification of the method of Lowry (Bio-Rad, Hemel Hempstead, Herts, UK). Data are presented as the fold induction of cAMP after treatment with iloprost, where fold induction was calculated relative to the control samples.

\section{Statistics}

Where appropriate, data were subjected to statistical analysis with ANOVA and Fisher's protected least significant difference tests (Statview 4.0; Abacus Concepts Inc., Piscataway, NJ, USA) and statistical significance was accepted when $P<0.05$.

\section{Results}

The temporal pattern of PGIS mRNA expression in the human endometrium across the menstrual cycle was studied by quantitative RT-PCR. PGIS mRNA was detected in all samples of human endometrium examined (Fig. 1a). Relative expression was significantly higher in the menstrual phase of the cycle compared with all other phases (14.49 \pm 5.92 vs $2.28 \pm 0.74$ for EP-MP; $1.25 \pm 0.33$ for 

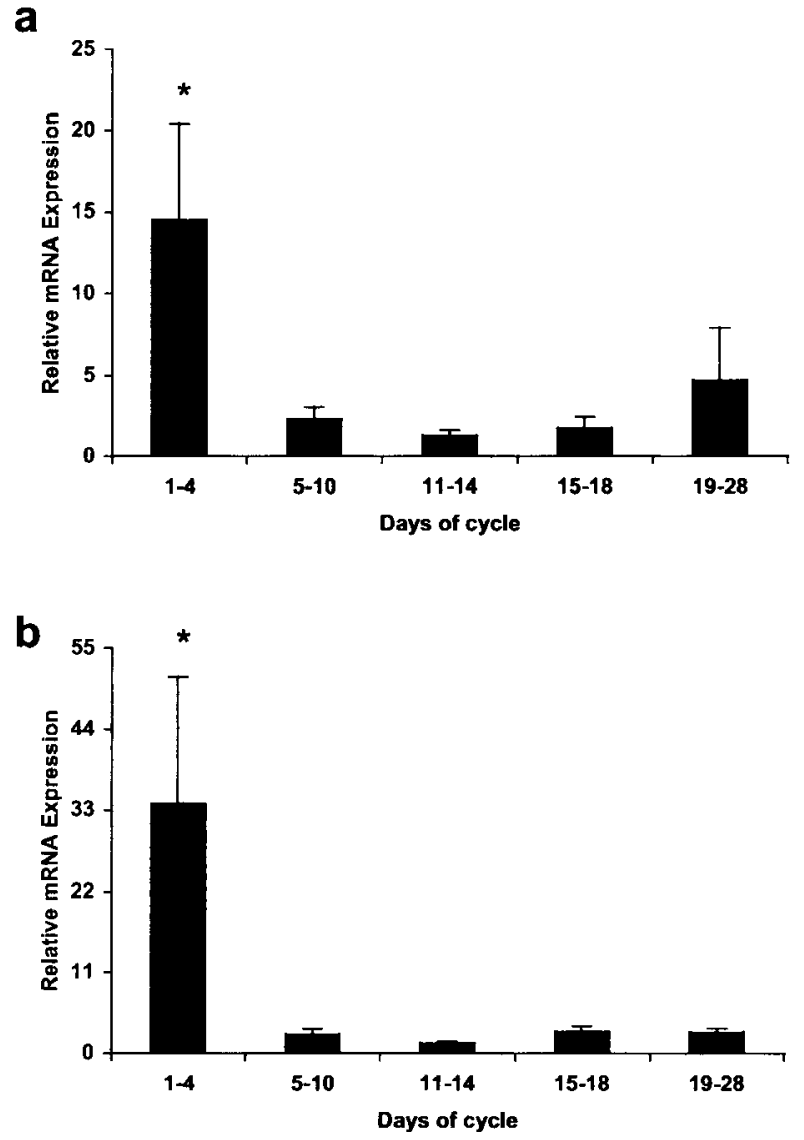

Figure 1 Quantitative RT-PCR of (a) PGIS and (b) IP receptor in the human endometrium across the menstrual cycle. Results are expressed as the mean \pm S.E.M. of relative mRNA expression levels. $* P<0.05$.

LP-Ov; $1.75 \pm 0.67$ for ES and $4.7 \pm 3.15$ for MS-LS; $P<0.05$ for all comparisons). Similarly, the temporal pattern of IP receptor mRNA expression across the menstrual cycle was assessed by quantitative RT-PCR and IP receptor mRNA was detected in all samples of human endometrium examined (Fig. 1b). Relative expression was significantly higher in the menstrual phase of the cycle compared with all other phases (33.94 \pm 17.2 vs $2.62 \pm 0.7$ for EP-MP; $1.36 \pm 0.25$ for LP-Ov; $2.95 \pm 0.76$ for $\mathrm{ES}$ and $2.87 \pm 0.53$ for MS-LS; $P<0.001$ for all comparisons).

Immunohistochemical staining for PGIS was performed in full thickness human endometrial biopsies collected from across the menstrual cycle. A similar pattern of staining was observed in tissue sections from proliferative and secretory phases (Fig. 2 is a representative sample of endometrial tissue collected during the proliferative phase). Cytoplasmic and nuclear immunoreactivity was detected in glandular epithelial cells in the basal (Fig. 2b) and functional (Fig. 2c) layers. Stromal cell reactivity was also present in both layers, but with greater reactivity in the functional than in the basal layer (Fig. 2a).
Endothelial cell staining was detected in the microvasculature in both endometrial layers and reactivity was also present in myometrial smooth muscle cells (enlarged area in Fig. 2a).

The site of expression of the IP receptor was studied by in situ hybridisation and immunohistochemistry. IP receptor mRNA expression was detected in endometrial samples collected during the menstrual and proliferative phases of the menstrual cycle. IP receptor expression was localised to glandular epithelial and stromal cells in the basal and functional layers of the endometrium (Fig. 3b-d). In addition, expression was present in myometrial smooth muscle cells (Fig. 3a) and in endothelial cells lining vessels in the functional and basal layers of the endometrium and at the basal-myometrial junction (Fig. 3a and c). Immunohistochemical staining for IP receptor protein was detected throughout the menstrual cycle in the cytoplasm and nuclei of glandular epithelial cells in both basal and functional layers (Fig. 4a-c). Similar to PGIS immunoreactivity, IP receptor stromal cell staining was stronger and more widespread in the functional layer (Fig. 4c) compared with the basal layer (Fig. 4b). IP receptor protein expression was also localised to endothelial cells throughout the microvasculature and was present in myometrial smooth muscle cells.

To investigate the functionality of the IP receptor, cAMP generation in response to iloprost (a $\mathrm{PGI}_{2}$ analogue) treatment was assessed in endometrial biopsy tissue collected across the menstrual cycle (Fig. 5). Cyclic AMP generation in response to $100 \mathrm{nmoll}^{-1}$ iloprost was significantly higher in endometrial samples collected during the proliferative phase compared with the secretory phase $(4.83 \pm 0.74$ fold increase vs $2.07 \pm 0.39$ fold increase; $n=4$ for each group; $P<0.05$ ).

\section{Discussion}

This study demonstrates the expression of PGIS and IP receptor genes in the human endometrium and shows significant up-regulation of both during menstruation. PGIS is the terminal enzyme that leads to synthesis of $\mathrm{PGI}_{2}$ in target tissues (Kniss 1999). The higher expression level of PGIS during menstruation supports previous observations reporting a temporal pattern of $\mathrm{PGI}_{2}$ secretion by the human endometrium across the menstrual cycle; $\mathrm{PGI}_{2}$ concentrations are maximal in uterine venous blood during menstruation (Goodfellow et al. 1982). The elevated expression of IP receptor during menstruation suggests that $\mathrm{PGI}_{2}$ synthesis and IP receptor are temporally regulated to induce their effects on target cells. This is supported by the maximal iloprost-induced CAMP response observed in the endometrium collected during the menstrual/proliferative phases. The IP receptor has been shown to couple to $\mathrm{G}_{\mathrm{s}}$ proteins which are linked to increases in cAMP generation (Narumiya et al. 1999). Although only the protein kinase A pathway was 


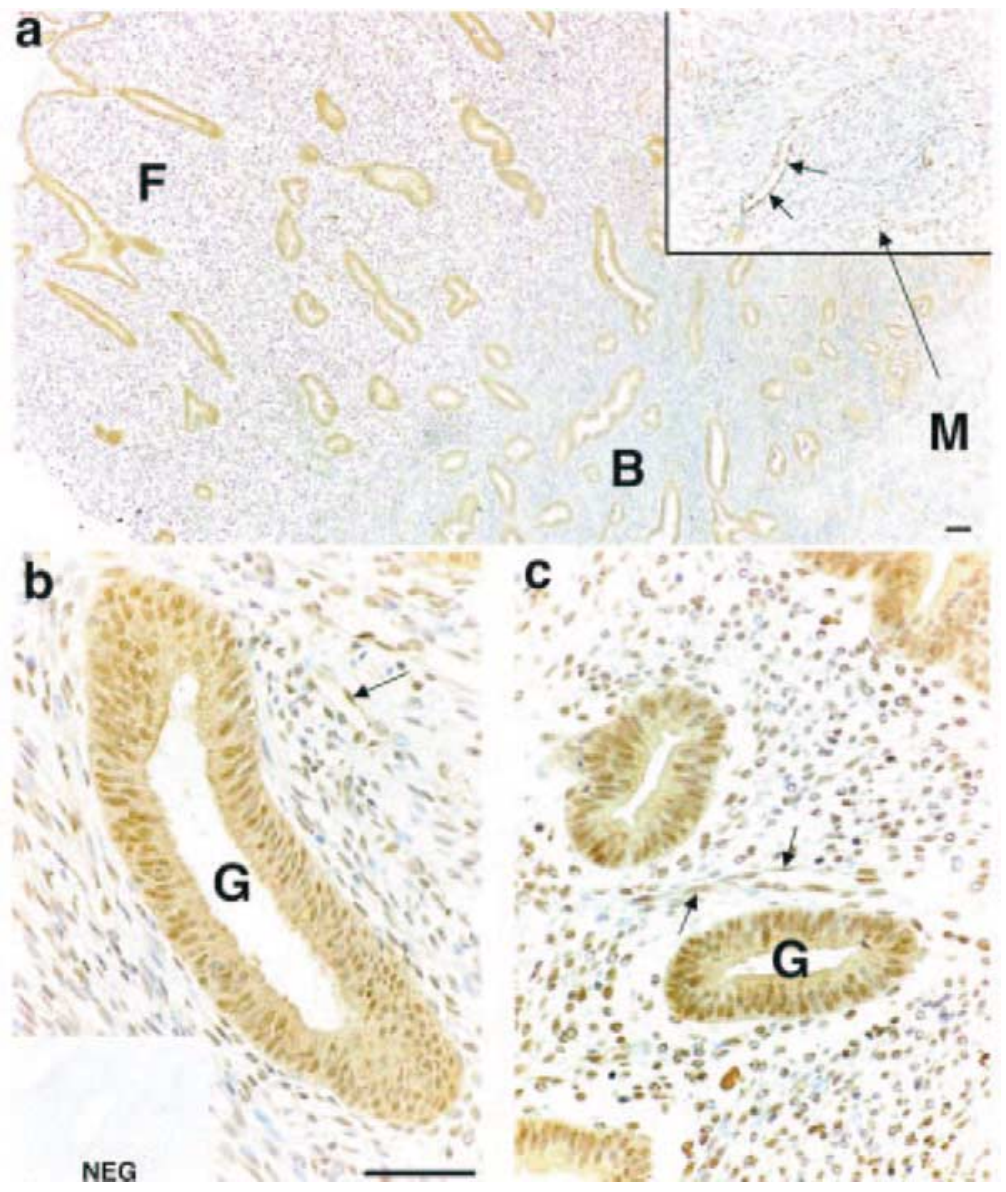

Figure 2 Immunohistochemical localisation of PGIS in human endometrial tissue (functional layer and basalmyometrial junction) collected in the proliferative phase of the menstrual cycle. Strong staining was detected in the glandular epithelial cells $(\mathrm{G})$ in basal (B) and functional $(\mathrm{F})$ layers $(\mathrm{a}-\mathrm{c})$ and in smooth muscle cells in the myometrium (M) (enlarged area in inset to a). Stromal staining was detected in the basal (b) and the functional layer (c) and endothelial cell reactivity was present in blood vessels (indicated by arrows) in all layers. NEG, negative control; scale bars $=50 \mu \mathrm{m}$. investigated in this study, it is predicted that the IP receptor may activate other signalling pathways in the human endometrium, as has been shown recently for other prostaglandin receptors (Jabbour \& Boddy 2003, Milne \& Jabbour 2003). Such diverse signalling pathways may lead to differential activation of target genes that can promote various phenotypic changes on target cells. In addition to the classical G protein-coupled IP receptor, recent evidence suggests that prostacyclin functions via the nuclear peroxisome proliferator-activated receptor delta (PPARס) (Lim \& Dey 2002). The importance of this mechanism in prostacyclin activity in non-pregnant endometrium is not known. However, it is unlikely to be the predominant signalling pathway, since expression of PPAR $\delta$ in the normal human endometrium is minimal (Tong et al. 2000).

The factors that regulate the expression of the PGIS and IP receptor during menstruation in the human endometrium are not clear. It is likely that this temporal expression is regulated by steroid hormones as has been postulated for other prostanoids and their receptors (Milne et al. 2001, Milne \& Jabbour 2003). Oestradiol-17 $\beta$ has been shown to stimulate the secretion of $\mathrm{PGI}_{2}$ in endometrial stromal cells (Levin et al. 1992). Whether this is associated with up-regulation in the expression of the IP receptor is unclear. Expression of the IP receptor may also be regulated by $\mathrm{PGI}_{2}$ or other prostaglandins. Expression of PGIS and synthesis of $\mathrm{PGI}_{2}$ is induced by COX-2 (Caughey et al. 2001), which is up-regulated during the time of menstruation (Jones et al. 1997). It is also plausible that local mediators within the endometrium may play a role in the regulation of $\mathrm{PGI}_{2}$ synthesis and/or expression of its receptor. For instance, $\mathrm{PGI}_{2}$ is a mediator of the protective effects of vascular endothelial growth factor (VEGF) on the vasculature (Zachary 2001) and $\mathrm{PGI}_{2}$ biosynthesis is up-regulated by VEGF via ERK-mediated cytosolic phospholipase $\mathrm{A}_{2}$ activation and arachidonic acid mobilisation (Zachary \& Gliki 2001).

PGIS and IP receptor expression have been co-localised to multi-cellular compartments of the human endometrium. These include stromal, glandular epithelial, endothelial and smooth muscle cells. This suggests that $\mathrm{PGI}_{2}$ acts in an autocrine/paracrine manner within the human endometrium to induce its cellular effects. PGIS and IP receptor immunoreactivities have been demonstrated previously in myocytes, vascular smooth muscle cells and endothelial cells in pregnant and non-pregnant human myometrium (Moonen et al. 1986, Chegini \& Rao 1988, Giannoulias et al. 2002). To our knowledge, however, this 


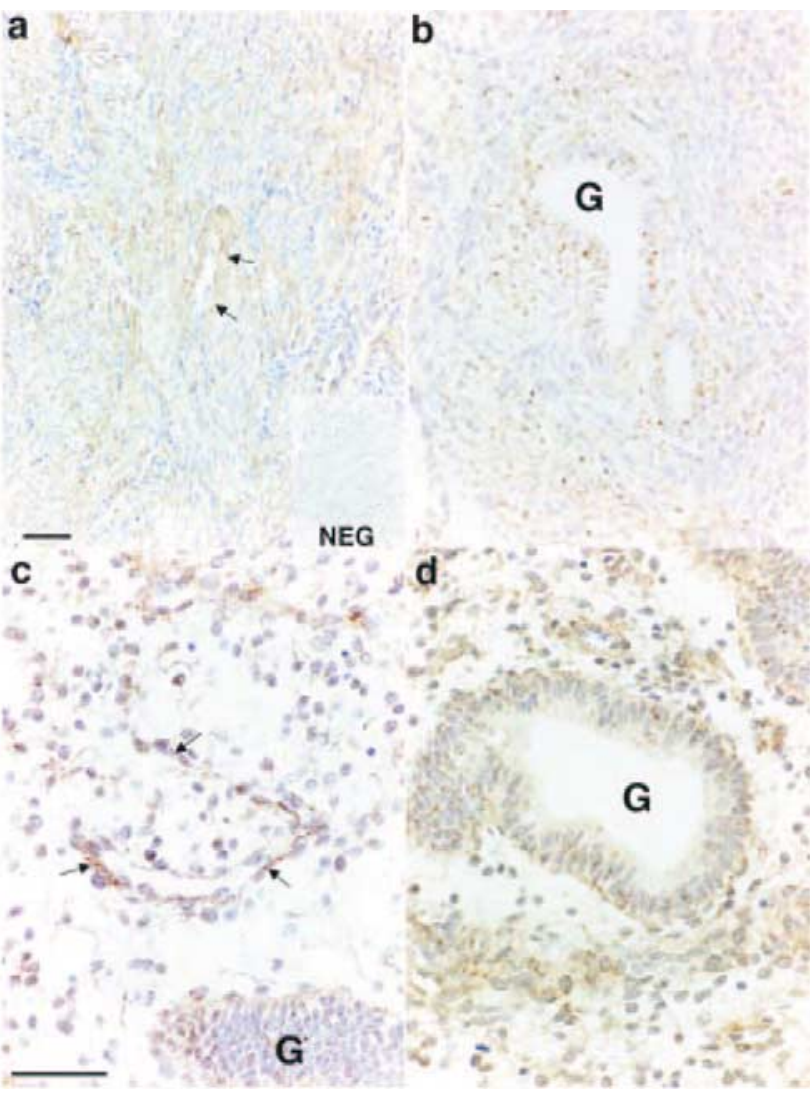

Figure 3 In situ hybridisation of IP receptor in sections of human endometrial tissue collected in the proliferative phase of the menstrual cycle. IP receptor was expressed in smooth muscle cells in the myometrium (a) and reactivity was also present in glandular epithelial cells (G) and in stromal cells in both the basal layer (b) and the functional layer (c and d). IP receptor was also expressed in vascular endothelial cells (indicated by arrows in a and c). NEG, negative control; scale bars $=50 \mu \mathrm{m}$.

the first report of localisation of PGIS and IP receptor in glandular epithelial and stromal cells within the human endometrium. Previous studies using autoradiography with $\left[{ }^{3} \mathrm{H}\right] \mathrm{PGl}_{2}$ on human uterine tissue failed to demonstrate $\mathrm{PGl}_{2}$ binding sites in epithelial cells (Chegini \& Rao 1988), although in that study binding sites were demonstrated in myometrial smooth muscle. This inconsistency with findings presented herein may reflect differences in the sensitivity of the methods used. Interestingly, stromal expression of PGIS and IP receptor was highest in the functional layer of the endometrium. In premenopausal women, the human endometrium undergoes phases of proliferation and apoptosis during successive menstrual cycles. These phases are observed predominantly in the functional layer of the endometrium, which is shed at menstruation before regenerating during the proliferative phase of the subsequent menstrual cycle. Hence, this spatio-temporal expression of PGIS and IP receptor may be crucial for, and in keeping with, its predicted role in menstruation.

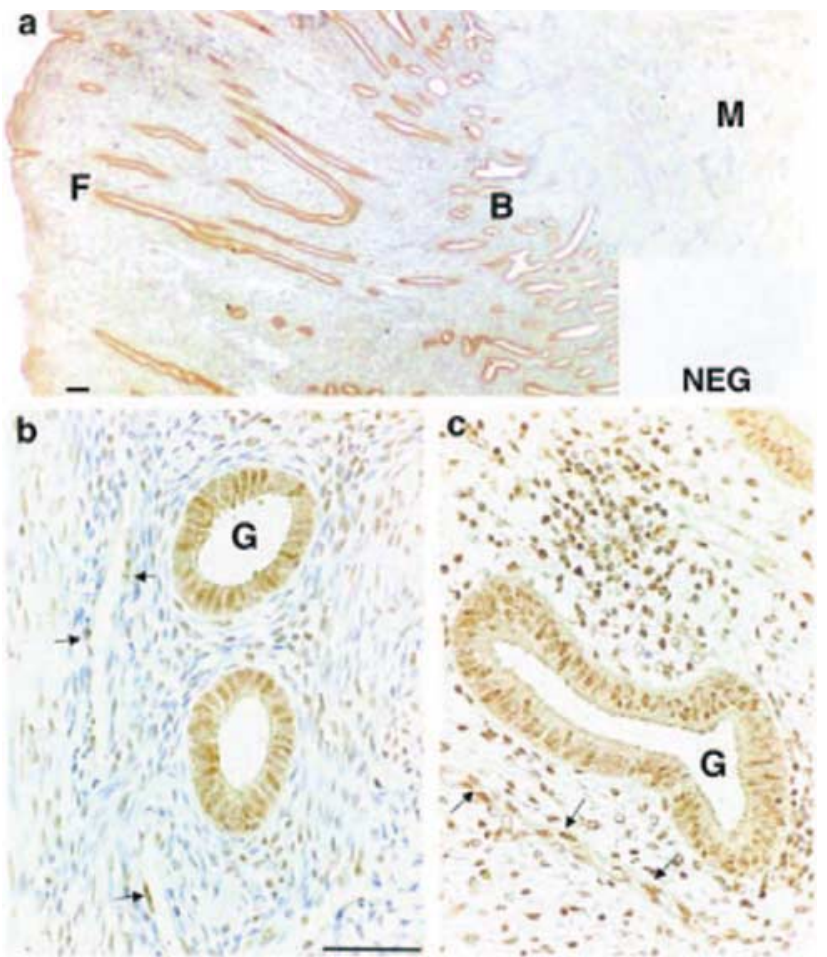

Figure 4 Immunohistochemical localisation of IP receptor in human endometrial tissue (functional layer and basal-myometrial junction) collected in the proliferative phase of the menstrual cycle. Glandular epithelial staining $(\mathrm{G})$ was present in both basal (B) and functional (F) layers and reactivity was detected in smooth muscle cells in the myometrium (M) (a-c). Stromal cell staining was present throughout the endometrium, but was stronger in the functional layer (c) compared with the basal layer (b). Endothelial cells throughout the endometrium and at the basal-myometrial junction also exhibited positive reactivity for the IP receptor (indicated by arrows in b and c). NEG, negative control; scale bars $=50 \mu \mathrm{m}$.

Baird et al. (1996) have postulated a role for $\mathrm{PGl}_{2}$ in menstruation based on its myometrial smooth muscle and vascular relaxation effects and inhibition of platelet aggregation. This would counteract the effects of other

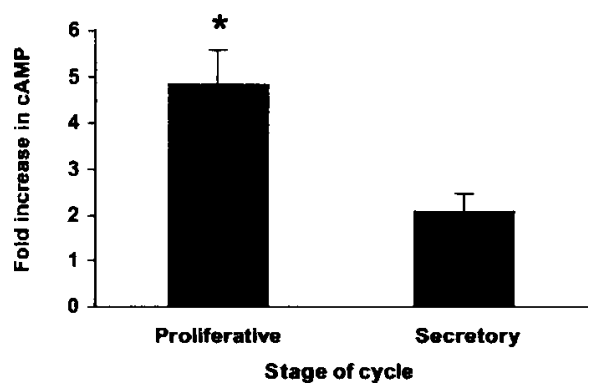

Figure 5 Fold increase in cAMP generation in endometrial tissue collected from the proliferative $(n=4)$ and secretory $(n=4)$ phases of the menstrual cycle in response to $100 \mathrm{nmol} \mathrm{I}^{-1}$ iloprost. Results are expressed as the mean \pm S.E.M. of fold cAMP induction. $* P<0.05$. 
prostaglandins such as $\mathrm{PGF}_{2 \alpha}$, which causes vasoconstriction and myometrial smooth muscle contraction (Crankshaw \& Dyal 1994). It is also likely that $\mathrm{PGI}_{2}$ is involved in the repair of the vascular bed, since it has protective effects on the endothelium by inhibiting vascular smooth muscle proliferation and enhancing endothelial cell survival (Zachary 2001). The increased expression of PGIS and IP receptor during menstruation is also consistent with a role for $\mathrm{PGI}_{2}$ in the aetiology of menorrhagia. Evidence for this has been provided previously by studies of dysfunctional menstrual bleeding, which have demonstrated increased prostaglandin synthesis including $\mathrm{PGI}_{2}$ (Smith et al. 1981b, Cameron et al. 1987) or increased synthesis of $\mathrm{PGI}_{2}$ relative to thromboxane $\mathrm{A}_{2}$ (Makarainen \& Ylikorkala 1986b) in uterine tissue from women with excessive blood loss relative to controls. Whether IP receptor expression and signalling are also elevated in the endometrium of women with dysfunctional menstruation remains to be established.

In summary, this study has demonstrated temporal expression of PGIS and IP receptor in the non-pregnant human endometrium. Expression of both genes is highest during the menstrual phase and is localised to multi-cellular compartments. The function of $\mathrm{PGI}_{2}$ in the human endometrium is linked to the protein kinase A pathway during menstruation. Future studies will elucidate the exact role of $\mathrm{PGI}_{2}$ in menstruation and the mechanisms of its signalling in the human endometrium.

\section{Acknowledgements}

The authors would like to acknowledge Mrs Sheila Boddy for assistance with cAMP assays and Mrs Catherine Murray for patient recruitment. This research was funded by the Medical Research Council awarded to H N J (Unit Support) and H O D C (programme grant no. 0000066).

\section{References}

Baird DT, Cameron ST, Critchley HO, Drudy TA, Howe A, Jones RL, Lea RG \& Kelly RW 1996 Prostaglandins and menstruation. European Journal of Obstetric Gynecology and Reproductive Biology $7015-17$.

Cameron IT, Leask R, Kelly RW \& Baird DT 1987 Endometrial prostaglandins in women with abnormal menstrual bleeding. Prostaglandins Leukotrienes and Medicine 29 249-257.

Caughey GE, Cleland LG, Penglis PS, Gamble JR \& James MJ 2001 Roles of cyclooxygenase (COX)- 1 and COX-2 in prostanoid production by human endothelial cells: selective up-regulation of prostacyclin synthesis by COX-2. Journal of Immunology $\mathbf{1 6 7}$ 2831-2838.

Chegini N \& Rao CV 1988 The presence of leukotriene C4- and prostacyclin-binding sites in nonpregnant human uterine tissue. Journal of Clinical Endocrinology and Metabolism 66 76-87.

Crankshaw DJ \& Dyal R 1994 Effects of some naturally occurring prostanoids and some cyclooxygenase inhibitors on the contractility of the human lower uterine segment in vitro. Canadian Journal of Physiology and Pharmacology 72 870-874.
Dyal R \& Crankshaw DJ 1988 The effects of some synthetic prostanoids on the contractility of the human lower uterine segment in vitro. American Journal of Obstetric Gynecology 158 281-285.

Fortier I, Patry C, Lora M, Samadfan R \& de Brum-Fernandes AJ 2001 Immunohistochemical localization of the prostacyclin receptor (IP) human bone. Prostaglandins Leukotrienes and Essential Fatty Acids 65 79-83.

Giannoulias D, Alfaidy N, Holloway AC, Gibb W, Sun M, Lye SJ \& Challis JR 2002 Expression of prostaglandin $I_{2}$ synthase, but not prostaglandin E synthase, changes in myometrium of women at term pregnancy. Journal of Clinical Endocrinology and Metabolism 87 5274-5282.

Goodfellow CF, Paton RC, Salmon JA, Moncada S, Clayton JK, Davies JA \& McNicol GP 1982 6-Oxo-prostaglandin $F_{1 \alpha}$ and thromboxane $B_{2}$ in uterine vein blood - a possible role in menstrual bleeding. Thrombosis and Haemostasis 48 9-12.

Jabbour HN \& Boddy SC 2003 Prostaglandin $E_{2}$ induces proliferation of glandular epithelial cells of the human endometrium via extracellular regulated kinase 1/2-mediated pathway. Journal of Clinical Endocrinology and Metabolism 88 4481-4487.

Jones RL, Kelly RW \& Critchley HO 1997 Chemokine and cyclooxygenase-2 expression in human endometrium coincides with leukocyte accumulation. Human Reproduction 12 1300-1306.

Kniss DA 1999 Cyclooxygenases in reproductive medicine and biology. Journal of the Society for Gynecological Investigations 6 285-292.

Levin JH, Stanczyk FZ \& Lobo RA 1992 Estradiol stimulates the secretion of prostacyclin and thromboxane from endometrial stromal cells in culture. Fertility and Sterility $\mathbf{5 8} 530-536$.

Lim H \& Dey SK 2002 A novel pathway of prostacyclin signaling hanging out with nuclear receptors. Endocrinology 143 3207-3210.

Lumsden MA \& Baird DT 1986 The effect of intrauterine administration of prostacyclin on the contractility of the non-pregnant uterus in vivo. Prostaglandins 31 1011-1022.

Lumsden MA, Kelly RW, Abel MH \& Baird DT 1986 The concentrations of prostaglandins in endometrium during the menstrual cycle in women with measured menstrual blood loss. Prostaglandins Leukotrienes and Medicine 23 217-227.

Makarainen L \& Ylikorkala O 1986 Primary and myoma-associated menorrhagia: role of prostaglandins and effects of ibuprofen. British Journal of Obstetrics and Gynaecology 93 974-978.

Milne SA \& Jabbour HN 2003 Prostaglandin $\mathrm{PGF}_{2 \alpha}$ receptor expression and signaling in human endometrium: role of $\mathrm{PGF}_{2 \alpha}$ in epithelial cell proliferation. Journal of Clinical Endocrinology and Metabolism 88 1825-1832.

Milne SA, Perchick GB, Boddy SC \& Jabbour HN 2001 Expression, localization, and signaling of $\mathrm{PGE}_{2}$ and EP2/EP4 receptors in human nonpregnant endometrium across the menstrual cycle. Journal of Clinical Endocrinology and Metabolism 86 4453-4459.

Moonen P, Klok G \& Keirse MJ 1986 Distribution of prostaglandin endoperoxide synthase and prostacyclin synthase in the late pregnant uterus. British Journal of Obstetrics and Gynaecology 93 255-259.

Narumiya S, Sugimoto Y \& Ushikubi F 1999 Prostanoid receptors: structures, properties, and functions. Physiology Reviews $\mathbf{7 9}$ $1193-1226$.

Noyes RW, Hertig AT \& Rock J 1975 Dating the endometrial biopsy. American Journal of Obstetrics and Gynecology 122 262-263.

Prentice A 2000 Health burdens of menstrual disorders. In Disorders of the Menstrual Cycle, pp 13-23. Eds S O'Brien, I Cameron \& A Maclean. London: RCOG Press.

Smith SK \& Kelly RW 1988 The release of $\mathrm{PGF}_{2}$ alpha and $\mathrm{PGE}_{2}$ from separated cells of human endometrium and decidua. Prostaglandins Leukotrienes and Essential Fatty Acids 33 91-96.

Smith SK, Abel MH, Kelly RW \& Baird DT 1981a Prostaglandin synthesis in the endometrium of women with ovular dysfunctional uterine bleeding. British Journal of Obstetrics and Gynaecology $\mathbf{8 8}$ 434-442. 
Smith SK, Abel MH, Kelly RW \& Baird DT $1981 b$ A role for prostacyclin $\left(\mathrm{PGI}_{2}\right)$ in excessive menstrual bleeding. Lancet 1 522-524.

Smyth EM \& FitzGerald GA 2002 Human prostacyclin receptor. Vitamins and Hormones 65 149-165.

Tong BJ, Tan J, Tajeda L, Das SK, Chapman JA, DuBois RN \& Dey SK 2000 Heightened expression of cyclooxygenase-2 and peroxisome proliferator-activated receptor-delta in human endometrial adenocarcinoma. Neoplasia 2 483-490.

Wilhelmsson L, Wikland $\mathbf{M}$ \& Wiqvist $\mathbf{N} 1981 \mathrm{PGH}_{2}, \mathrm{TxA}_{2}$ and $\mathrm{PGI}_{2}$ have potent and differentiated actions on human uterine contractility. Prostaglandins 21 277-286.
Zachary I 2001 Signaling mechanisms mediating vascular protective actions of vascular endothelial growth factor. American Journal of Physiology. Cell Physiology $\mathbf{2 8 0}$ C1375-C1386.

Zachary I \& Gliki G 2001 Signaling transduction mechanisms mediating biological actions of the vascular endothelial growth factor family. Cardiovascular Research 49 568-581.

Received 21 July 2003

First decision 11 September 2003

Accepted 25 September 2003 